\title{
Survey on sustainable mechanisms for financing essential drugs at Loumbila in Burkina Faso
}

\author{
Hamado Saouadogo ${ }^{1}$, Koffi Miwonovi Amoussou ${ }^{2}$, Laurent Ouedraogo ${ }^{3}$ \\ ${ }^{1}$ Public and International health Pharmacist, MOH, Burkina Faso. 01 BP 3409 Ouagadougou 01 Burkina Faso \\ ${ }^{2} \mathrm{MOH}$, Boulsa Health District in Centre Northern region \\ ${ }^{3}$ Medical Doctor, Ph D Public Health, Maître de conférences agrégé de Santé publique, UFR/SDS, University of Ouagadougou, Burkina Faso
}

\section{Email address:}

christdonaldh@yahoo.co.uk (H. Saouadogo)

\section{To cite this article:}

Hamado Saouadogo, Koffi Miwonovi Amoussou, Laurent Ouedraogo. Survey on Sustainable Mechanisms for Financing Essential Drugs at Loumbila in Burkina Faso. Science Journal of Public Health. Vol. 2, No. 5, 2014, pp. 486-493. doi: 10.11648/j.sjph.20140205.27

\begin{abstract}
In Burkina Faso, households are the main source of health financing. Based on out-of-pocket health payments, the current system is a major cause of poverty. The purpose of this study is to contribute to the improvement of local health funding in Loumbila and throughout the country. A descriptive and analytical study was conducted among 271 household heads, 3 health committee members, the top state official in the village (préfet), and the secretary general of the municipality between 25 June and 5 August 2010. A survey guide and questionnaires were used to collect data. The crossanalytical and descriptive survey was used to collect, process, analyze and discuss the results. The results of the survey indicate that $82.3 \%$ of the participating households were willing to contribute to the creation of a municipal health fund in the village. The study founds that the average contribution rate of each household was $9 \%$ of the annual household income. The harvest period (in the case of farmers) or any adapted period (in the case of other households) is the best periods for collecting funds. The findings suggest that the municipal committee will need to be responsible for managing and coordinating the municipal health fund. This requires the participation of the state, health districts, NGOs (NonGovernmental Organizations), and others partners. It is estimated that the cost of effective treatment for the ten most priorities diseases in the village in 2010 was 4,011,300 FCFA (West and Central Africa French speaking countries currency). If all the households in the village were to contribute to the municipal health fund, the total amount of contributions would amount to 15,575,515 FCFA. Under this system, all households within the village can have access to essential drugs. The municipal health fund will also have some reserves for performing municipal development boards and institutions, for improving the independence and sustainability of the system.
\end{abstract}

Keywords: Funding, Essential Medicines, Households, Loumbila, Burkina Faso

\section{Introduction}

Community Health financing is a mechanism whereby households pay their access to health care for a given set of services and thus participate in the management and organization of health services in the country [1].

Thus, essential drugs are those that will meet the health priority needs of the community in terms of essential health care. These essential drugs are chosen because of their interest in public health, efficacy, safety and effectiveness compared to other drugs [2].

In many developed countries, more than $70 \%$ of pharmaceutical products are financed by the national budget managed by the government. There, health insurance systems can provide better financial access [2, 3]. But, in low and middle income countries, government expenditures do not cover basic pharmaceutical needs of the majority of the population. There is no health sharing risk mechanism and 50 to $90 \%$ of medicines are paid by patients themselves. The average health insurance coverage is $35 \%$ in Latino America, $10 \%$ in Asia and 8\% in Africa [2].

Direct payments are therefore the main mechanism for essential drugs financing [4]. Yet these direct payments are responsible for "household catastrophic spending's". Thus, the occurrence of disease becomes a source of further impoverishment of already poor households [5].

Then, over a third of the world population has no access to drugs because of these direct payments [2].

In Burkina Faso, essential drugs are $90 \%$ available in 
public health centers [6]. The majority of households $(77.3 \%)$ are living in rural areas [7]. Out of these households $(56.5 \%)$ are living with less than $625 \mathrm{CFA}$ francs per day and $81.2 \%$ from the same population are living with less than 1,000 CFA per day according to the World Bank [8]. Unfortunately, these households are the main sources for essential drugs financing through the direct payments mechanisms (out-of-pocket) which is $38.4 \%$ of Burkina Faso national health fund in 2008 [9].

In 2007, WHO, the World Bank, the Ministries of Finance and Health conducted studies which confirmed that financial barriers are the main challenge for household to have access to essential medicines. These surveys have indeed demonstrated that direct payments of essential drugs mechanisms (out-of-pocket) is responsible of households broken and catastrophic spending's in rural areas where people are still living with poverty and misery [6]. While $77.30 \%$ of the populations are living in rural areas of Burkina Faso under financial poverty [10] yet other sources of essential drugs and health financing come from international aid which is not a charity act [11]. So, searching for alternative essential drug financing mechanisms that will improve household affordability is a real concern for households, politics and public health specialists in the country [5].

Loumbila was selected from ten villages located within $25 \mathrm{~km}$ to Ouagadougou for this study. The distance of 25 $\mathrm{km}$ from Ouagadougou the main city of the country was accepted because of limited financial resources for the survey.

Loumbila village is located in Ziniaré health district, Oubritenga province of the Central Plateau Region of Burkina Faso. It is close to Ouagadougou the political capital at the East and from $25 \mathrm{~km}$. In 2006, Loumbila total population was 1,696 persons and 292 households. The average age is 21 years and $49.7 \%$ are youth under 15 years. The population growth rate is $2.52 \%$ per year. But in the region, $58.6 \%$ are living with less than $625 \mathrm{~F} \mathrm{CFA}$ and $83 \%$ of adults are illiterate [10].

Agriculture and herders (livestock) are the two main activities of the municipality while the employment rate remains low. The presence of a dam with a capacity of 36 million $\mathrm{m} 3$ and many water reservoirs facilitates the development of income generating activities.

The main diseases in the village are malaria, lower respiratory infections, diarrhea, wounds, upper respiratory tract infections, skin diseases and intestinal parasites. The epidemic-prone diseases such as meningitis, cholera, measles, tuberculosis, leprosy, filariasis and HIV / AIDS infections are the states' special interest and concern. The overall mortality rate is $14.4 \%$ in 2010.To contribute for improving sustainable and autonomous health system financing in Burkina Faso, it is important to collect, assess, process and analyze each household's proposal for sustainable mechanisms for essential medicines financing.

Rural areas are first affected and the lack of national health insurance scheme justifies carrying out this study with rural households in order to understand their needs and them own proposal about the sustainable mechanisms for improving essential medicines affordability. This survey aims to participate for creating, improving and developing sustainable essential medicines financing mechanisms for efficiency and equity access in rural areas. It was well to describe the heads of household characteristics (demographic, cultural and economic), to analyze all proposals from household in each social group for improving essential medicine financing sustainable mechanisms in Loumbila.

\section{Survey Population and Methods}

\subsection{Population of the Survey}

That survey population is defined according to each actor's role for improving essential medicine affordability in the village. The municipal councilors, the members of health Management Committee (COGES) and the Head of public administration (Préfet) will be considered one by one. Some of them who are living in the village and are a head of household will be taken in one social group of the heads of household. Those community leaders could have a significant impact for organizing the population and improving the sustainable mechanism for essential medicine financing in the village. Thus the following community groups of that study population is:

- Heads of household from Loumbila village ;

- Municipal councilors from the village ;

- Health Management Committee members ;

- Head of public administration in the village (Préfet).

\subsection{Survey Methods}

This study is cross-analytical and descriptive. It took place from 25 June to 05 August 2010. The sample size is all the households of the village. The calculations were done by national institute of statistics and development of Burkina Faso. It consists of all 292 heads of household, administrative and health authorities in the rural Loumbila [17]. All heads of household residents in the village, administrative and health authorities available to participate in the study were included. But those non Loumbila residents were excluded. In Loumbila village, the heads of household were described according to socioeconomic status and $77.1 \%$ are farmers, $10.3 \%$ from public sector employment, $7 \%$ from private sector and $5.6 \%$ from informal sector (non regulated market). This survey indicators are the attendance rate for health services, essential medicines funding mechanisms, arranging essential drugs financing from the households, monitoring, supervision and safety and security of prepayment system wherever it is taken place in the village. Data collection was performed by two pharmacy students. In some cases, translation from French to local languages was made by local French-speakers from Loumbila. Tools for data collection consisted of individual interview guides and 
questionnaires. Techniques of data collection have included the use of available publications, individual interviews and the distribution of written questionnaires. The pre-test was first performed on five heads of households drawn randomly before to start of the investigation. It allowed making amendments and further adapting the tools of data collection to field realities. The survey was conducted from household to household and neighborhood for the entire village. The move was made from compound to compound. Written authorization of the study was given by administrative authorities. The collected data were typed with double recovery by two people. As a result, they were processed and analyzed with the software EPI-INFO version 3.5.1 2008, MS Excel and MS Word 2007. Data was collected anonymously with the consent of each member of the survey population. There were no clinical actions or direct consequences of that study on the human body. All interviews were made respecting Loumbila traditions, culture with the agreement from the ethical committee of the $\mathrm{MOH}$.

\section{Results}

\subsection{Characteristics of the Survey Sample}

The survey covered 276 persons including 271 heads of household residents, three members of Health Management Committee, the Head of public administration and the Secretary General of the village municipal council. Among the heads of household, $92.3 \%$ were male and $9.6 \%$ were over 60 years. The average household size was 7.4 persons. Among the heads of households, farmers were the most important number $(77.1 \%$ of the total). The results indicated that the estimated revenues by households and the average annual income was at least 400,000 FCFA. The public sector employees were the richest $(1,794,234$ FCFA). They are followed by private sector workers $(528,904$ FCFA). The less fortunate are farmers (423,334 FCFA) and the informal sector $(435,526.31$ FCFA). These revenues were split mainly for purchasing medicines or food (Table I).

Table 1. Distribution of heads of household by socio-economic and the average Household annual expenditure for purchasing medicines and food

\begin{tabular}{lll}
\hline Socio-economic groups & Average annual expenditure for the purchase of drugs (FCFA) & Average annual expenditure for food (FCFA) \\
\hline Farmers & 32,300 & 251,342 \\
Private sector employees & 38,105 & 231,143 \\
Public sector employees & 63,875 & 544,286 \\
Informal sector employees & 22,868 & 194,947 \\
Average in the village & 39,287 & 305,430 \\
\hline
\end{tabular}

\subsection{Proposed Mechanism for Essential Medicines Financing From Heads of Householder}

Heads of household interviewed had different proposals for the State contribution rate for essential medicines financing. According to each socio-economic heads of household groups, the state participation rate for essential medicines financing was different. Also, heads of household expressed their own need as sustainable mechanism for financing essential medicine: Among them, 94.5\% were not agreed with direct payments and out-ofpocket for affording essential medicines in the village. Also, $89.3 \%$ of heads of household were not agreed with a free fee of essential medicines. Also, $47.2 \%$ of them are not agreed with essential medicines donations from the government, other countries, international organizations and others philanthropists. By the way, all the heads of households $(82.3 \%)$ were agreed with essential medicine prepayment mechanisms for financing these medicines in the village. For example, public sector employees (92.9\%) were not agreed with out-of-pocket and direct payment as a sustainable mechanism for essential medicines financing. They are followed by farmers $(83.7 \%)$, private sector employees $(80 \%)$ and the informal sector actors $(78.9 \%)$. Finally, head of household (96.3\%), head of public administration, municipal secretary general and health management committee members were willing to participate for improving prepayment system in the village.

Table 2. Comparison of annual income, food expenditures and proposed fee per household for financing essential medicine in Loumbila ME (N = 292).

\begin{tabular}{lllllllc}
\hline $\begin{array}{l}\text { Average } \\
\text { household *(7.4 } \\
\text { persons) }\end{array}$ & $\begin{array}{l}\text { Average estimated } \\
\text { annual revenues } \\
\text { (CFA) }\end{array}$ & $\begin{array}{l}\text { Average annual } \\
\text { expenditure for drugs } \\
\text { purchasing (CFA) }\end{array}$ & $\mathbf{\%}$ & $\begin{array}{l}\text { Average } \\
\text { expenditure for } \\
\text { food (CFA) }\end{array}$ & \% & $\begin{array}{l}\text { Average households } \\
\text { participation (CFA) }\end{array}$ & $\begin{array}{c}\text { \% } \\
\text { Farmers }\end{array}$ \\
\hline $\begin{array}{l}\text { Private sector } \\
\text { agents }\end{array}$ & 523,334 & 32,300 & 7.63 & 251,342 & 59.37 & 49,025 & 11.58 \\
$\begin{array}{l}\text { Public sector } \\
\text { employees }\end{array}$ & $1,794,234$ & 38,105 & 7.20 & 231,143 & 43.70 & 53,280 & 10.07 \\
$\begin{array}{l}\text { Informal sector } \\
\text { employees }\end{array}$ & $435,528.31$ & 63,875 & 3.56 & 544,286 & 30.33 & 60,680 & 3.38 \\
Average & $795,500.08$ & 22,868 & 5.25 & 194,947 & 44.76 & 47,619 & 10.93 \\
\hline
\end{tabular}

* The average number of persons per household is used as the average household. If the average number of persons per household is 7.4 , the average household has 7.4 persons. 
The proposed participation rate was $9 \%$ of average household annual income (Table II). Farmers (74.6\%) and other heads of households are willing to pay their dues after the harvest. Thus, with 2,161 persons and 292 households estimated in Loumbila, it needs at least 4,011,300 FCFA (6,125 Euros) for financing essential medicines during priority diseases treatment in the village.

With volunteer's household member's participation system, one year bank account can be 15,375,515 CFA francs $(23,474$ euros). That sum is four times the village needs for financing essential medicines for priority diseases treatment (Table III).

Table 3. Estimated total resources of the cash funding of Essential Medicines in 2010.

\begin{tabular}{llllll}
\hline $\begin{array}{l}\text { Socio-professional } \\
\text { categories }\end{array}$ & $\%$ & $\begin{array}{l}\text { Per capita number } \\
\text { of social group }\end{array}$ & $\begin{array}{l}\text { Average amount of contribution } \\
\text { per person(FCFA) }\end{array}$ & $\begin{array}{l}\text { Average amount of dues per } \\
\text { household (n= 7.4) (FCFA) }\end{array}$ & Total \\
\hline Farmers & 77.1 & $1,666,13$ & 6,625 & 49,025 & $11,03817,88$ \\
Public sector employees & 10.3 & 222,58 & 8,200 & 60,680 & $1,825,180,6$ \\
Private sector agents & 7.0 & 151,27 & 7,200 & 53,280 & $1,089,144$ \\
$\begin{array}{l}\text { Informal sector } \\
\text { employees }\end{array}$ & 5.6 & 121,02 & 6,435 & 47,619 & $778,737,96$ \\
Average & 100 & 2,161 & 7,115 & 52,651 & $15,375,515$ \\
\hline
\end{tabular}

\section{Discussion}

\subsection{Survey Limitations and Biases}

The limits of the using method for realizing that survey are focused on the selection of villages close to the country capital at $25 \mathrm{~km}$. The choice of Loumbila might not be representative for any villages in the country. The less availability of the village Mayor and some health management committee members was also a limit of that survey. The estimation of the households annual financial resources, the households annual expenditures for affording medicines and the cost of essential medicines for priorities diseases treatment have a link with village data's availability and can be limiting to the survey. Other limits of that survey are the guides and questionnaires translated from French to local languages by villagers because; it could have an influence on some answers. Thus, many surveys were conducted in Loumbila village without any realization of these recommendations and this situation is discouraging some persons to care for that survey during the answer to the questionnaires.

\subsection{Heads of Household Social, Demographic, Cultural and Economic Situation}

In Loumbila, the average size of households is 7.4 persons. It was above the national average (5.9) and Central Plateau region (6.7). According to the National Institute of Statistics and Demography (INSD), from a size of seven persons, households start with difficult availability and affordability of most essential needs (medicines, feed, ect) [10]. By considering the average household annual expenditure for food from INSD (414, 996.4 FCFA) as reference, Loumbila village farmers and informal sector actors can be in catastrophic financial state if someone is sick in the family. That survey recommends to the Mayor for establishing Municipal Development Boards for improving household purchasing power and money availability. They will improve household's ability to pay for essential medicines prepayment system and throughout catastrophic spends from any group in the village [12].

\subsection{Household Proposal for Essential Medicines Financing Mechanisms}

\subsubsection{Essential Medicines Financing from the State Contribution}

In Burkina Faso, the government finances the new public health centers, needs on essential generic medicines kits $(M E G)$ for improving the Bamako Initiative recommendations. The government finances also public hospitals supply and procurement of some essential medicines more that 20 million FCFA per year per public hospital. Also, the medicines for prevention (EPI vaccines, prenatal consultation), malaria, HIV infections / STI, tuberculosis, neglected tropical diseases are financed by national budget and International aids. The obstetric and neonatal emergency ( $S O N U$ ) strategy is also financed by the government [6]. But all these grants are partially funded from international partners. Nowadays, despite these government strategies, only $42.6 \%$ of the populations have access to essential medicines in Burkina Faso. So, Loumbila household proposal to have the national budget contribution for essential medicines financing less than $25 \%$ shows their commitment for sustainable and independent mechanisms. It complies with health development experts from developed countries and International Organizations recommendations (Development partner's) [13].

\subsubsection{Households Essential Medicines Direct Payment Mechanism}

In Loumbila village, out-of-pocket, cost recovery and direct payment are the essential medicines financing mechanism for households at public health centers and pharmacies. The essential generic medicines pharmacy ( $D M E G$ in Fr) is located inside the public health centre (Health and Social Promotion Centre (CSPS in Fr). The private pharmacies are located in Ouagadougou. Some small pharmacies are located in the village but have not always essential value for households. When some one is 
sick, consulting and prescriptions fees become sources of impoverishment of families. "Sometime we sold goats, chickens, cereals for realizing essential medicines direct payment mechanism..." Heads of household said. Indeed, other surveys have indicated that households had to borrow or sell assets in order to afford prescriptions and medical care [4]. Without these resources, traditional solidarity (uncle, cousin, aunt, friends, colleagues, various relatives, etc...) is called for aid by patients. So, these situations are responsible for bad and late frequentation of health centers when some one is sick in the family. That is the reason; Loumbila village heads of household refuge that mechanism as sustainable essential medicines financing mechanism in the village. Direct payment mechanism affects health system performance and is also less profitable for households and health facilities. The results of this study are consistent with WHO expert recommendations [4].

\subsubsection{Free Fee Essential Medicines for Household's Mechanism}

In Loumbila village, the heads of households found that the Burkinabé government would never have sufficient money for financing essential medicines for all in the village. Also, the mismanagement of free medication is a big issue and caused serious damage to local pharmaceutical structures development. These conclusions are the same as those of WHO experts [4]. Indeed, the Bamako Initiative was adopted because the national budget could not fund alone health care. But nowadays, some free fee essential medicines for households mechanism is financed by International aid or state credit with World Bank and others International Banks. Yet with the economic and financial crises, financial partners are becoming more reluctant or pack their financial aid for making Burkina Faso more dependent to International Aid [4]. So if free fee essential medicines for households mechanism must be accepted as a principle for a groups of persons (schoolchildren, students, disabled, children under five, elderly), it could not be considered as sustainable mechanism for essential medicines financing in the village. Because it would undermine the pharmaceutical sector development in Loumbila. However, the Mayor and the Municipal council should develop innovative mechanisms (taxes on cigarettes, alcohol, speeding, parking, travel, telephone, etc) for financing essential medicines for schoolchildren, students, disabled, children under five, elderly as a same as in Scandinavian countries [27 to 32].

\subsubsection{Essential Medicines from Donations Mechanism}

Medicines and pharmaceutical devices donations are common practice in Burkina Faso from developed countries, philanthropist and International NGOs [14]. But in Loumbila village, some heads of households (47.2\%) rejected these gifts because they corresponded frequently with expired drugs or expiring that fuels the illicit market. Indeed, the destruction costs of these gifts are more expensive for communities when they could have used to pay for equivalent with local pharmaceutical structures [14]. These gifts also encourage the black market and weaken the official pharmaceutical products management and distribution in the village and throughout Burkina Faso. Thus, the risk of bypassing any local mobilization process to ensure a steady production or supply of drugs is important. Similarly, the risk of disrupting fragile started systems of management and distribution of pharmaceutical products is quite high [15]. So, essential medicines from donations mechanism can interfere with proper adhesion, prescription, drugs selection process, health care implementation and patients compliance with pharmaceutical guidelines based on clinical evidence [16]. So, Loumbila heads of households are right to refuge that mechanism as sustainable for financing essential medicine in the village.

\subsubsection{Households Essential Medicines Non Direct Payment Mechanism}

In Burkina Faso, the average household annual expenditure is estimated for 866,381 CFA francs $(1,323$ euros). One part is non-food expenditures $(52.1 \%)$ and the other part is food expenditures (47.9\%) [17]. But the household annual medicine expenditures occupied the most important part of non-food expenditures. So, the average household annual food expenditures were $44.54 \%$ during this study. There, $5.91 \%$ of those expenditures were for purchasing drugs for medical care. But for improving village insurance scheme, the households have a willingness to offer an average household annual contribution with $8.99 \%$ from each household total annual income. These results are the same like INSD publications. In France, people whose income exceeds the annual tax threshold must pay an annual fee of $8 \%$ on the amount of income above this threshold [18]. In Loumbila, some head of households with bad experience from mismanagement of health mutual and Mayor Corruptions had demanded rigorous involvement from the Head of public administration (Préfet). This group needs to have the village health insurance scheme, well managed without corruption for sustainable essential medicines financing. Indeed, some Health Mutuals had poor management and functioned badly with problems of abuse, poor organization, embezzlement and bad governance. A study from Nouna, a small city in Burkina Faso, indicates abuse, fraud and "opportunism" with health mutual members. Even drug prescriptions, patient reception and fraud providers are taken into account in the system [19]. Coverage of all households reduced the risk associated with these shortcomings. Many countries have moved closer from village health insurance scheme to universal health insurance coverage. It can gradually evolve into compulsory social insurance for specific groups, finally realizing levels of financial risk protection with much higher funds largely greater. The voluntary health insurance schemes were essential to help the development of several years after, universal coverage in France, Germany and 
Japan [4]. Ghana and Rwanda have been an example of best practice in national health insurance scheme in Africa [20]. The scandinavian countries systems can be a very good example for improving health and essential medicines affordability for everyone [27 to 32].

So, Burkina Faso has possibility now for improving national health insurance. It could start with village health insurance scheme as proposed by heads of household from Loumbila village to have essential medicines and primary health care services affordable for all.

\subsection{Household Members Participation to Municipal Health Insurance Scheme}

In Burkina Faso, the Law No. 055-2004/AN on General Code for Territorial Collectivities indicates at Article 91 that each collectivity should improve local health system from innovative mechanisms. The municipal council has a right to develop a contract with health management committee to have essential medicines and primary health care available and affordable for alls in the villages [12]. It can create a Municipal Health Fund or an account at a popular bank in the village for improving essential medicines affordability by the prepayment system. By the way, any actors (International private and public aid, philanthropy, Diaspora, local traditional aid, ect) may have banking with the village account for essential medicines affordability at the local Bank or Municipal Essential Medicines Prepayment Fund. As a result, the state through the Head of public administration in the village, the police, security agency and any others partners will always support these councils for creating and coordinating the system.

Indeed, any systems from Bismarckian model, the state has the task for ensuring the security of citizens by setting the framework for action boxes, control and recovery of these funds in case of financial crisis.

With Beveridge system, the social security funds are managed by the State, and controlled by Parliament [21]. In Africa, Rwanda is also working to harmonize the different funding mechanisms, in part by developing a national legal framework that governs the national insurance scheme in the country. In these cases, there is always a structure that ensures households resources for contribution to the health insurance scheme and social security.

The harvest was accepted by Loumbila village household for collecting each contribution. In Nkoranza, Ghana Republic, households have regretted that the contribution is requested at a bad period of year when household financial situation was poor [22]. A survey with health mutual members in Uganda revealed that the payment of household contribution spread over the years greatly facilitated their adherence [23]. On the other hand, households in the Nouna District, Burkina Faso had requested that the mutual adherence to take place during the harvest [24]. In Loumbila and Ouahigouya, the period of contributions is not a handicap for improving municipal health insurance scheme [12]. However, the contributions of farmers will be possible after the harvest but when their production will be converted into sufficient monetary value [25]. Agricultural product prices are higher at the third quarter of the year. But the livestock (herders) products have better prices during the holiday seasons (Christmas, End of the year, Easter, Muslim parties, ect.). So, organizing farmer products and livestock market is a best way to improve and further facilitate better adhesion and a good contribution of households. That is the reason it is important and necessary to create municipal development board for making the municipal health fund sustainable for the affording essential medicine and primary health care with the health management committee in the village. These institutions facilitate transactions, equalization and marketing of agricultural products in the village. Also, the municipal Council could have its own internal trade policy emphasizing local consumption of agricultural products and encouraging household member's participation to health risk sharing in the village. Since over the 1980, Burkina Faso had already set up successful local development board such as Faso yard, OFNACER, Faso Dan Fani, Cooperatives, etc.. [26]. Now, households need a strengthened strategy for improving the municipal health fund. After that, household will participate to municipal insurance scheme against the out-of-pocket. It is also help households to have greater purchasing power in the village. Some financial institutions for micro credit and microfinance exist in Burkina Faso and should work for some who don't have any possibility. Some are national microfinance service, microfinance and micro credit from World Bank, UNDP and the European Union. Its should become more involved in enabling households to achieve income-generating activities and improving their participation to the municipal health fund first and finally to municipal health insurance scheme. Municipal council members have to develop innovative mechanisms for funding school students, elderly and disabled participations to the system.

\section{Conclusion}

Municipal Insurance Scheme by the prepayment system is those who are adapted to Loumbila village household. It is adapted to the household social, economic and cultural situations because there, people are farmers, herders, income generating activities and informal sector actors. These products should be seller to become money for anyone participation to the health insurance scheme. That is the reason it is obligatory to create Municipal Development Boards for improving local products consumptions and market. It is well known from historical and during the national democratic revolution periods that people from Burkina Faso can improve their local development. This survey is to prove how rural people can have the same ideas as international experts. The heads of household from Loumbila village are able to be a part of that action with the local health and public administration. They need more economic, cultural and total independence 
against international aids. So, improving health risk sharing is a new challenge for the village Leaders and why not throughout Burkina Faso? These mechanisms are involved in the control of voters to elect the effectiveness of politic actions, improving democracy, against corruption and for good governance.

Rwanda and Ghana are pioneers and according to WHO; the health prepayment system could constitute to have a national insurance scheme for household social protection. It is will resolve for a long-term households health problems and develop good life and well been for any household members.

The Municipal Health Insurance Scheme is a health prepayment system and will work to reduce poverty and contribute for social, economic, cultural and environmental development in Loumbila village.

This social protection is developing in Burkina Faso step by step and will be a good employers, good way for local development. The farmers, informal and income generating actors who are the big majority of Burkina Faso people will have know well how to make more money and improve them family health care. It is well know that farmers and informal sectors are the main source of the country economic power with more than $60 \%$ of national GDP.

This study results are the same as INSD publications results and WHO expert's recommendations. So, the traditional social insurance mechanisms (Beveridge, Bismarck, Sebacko, form providence state, ect) are not well accepted by the heads of household. Here, this publication for indicated the real needs from rural households from low income country village.

Why not let other public health experts realize a similar survey in others villages for better understanding of rural household needs on health protection and essential medicine affordability?

The following recommendations are for developing sustainable essential medicine financing mechanisms in Loumbila village:

\subsection{To the Minister of Health, Burkina Faso}

To improve the empowerment of municipal health insurance scheme as health and essential medicine financing mechanism from national health politic document and action. It is a good way to achieve the Millennium Development Goals;

\subsection{For Health and Public Administrative from Loumbila Village (Préfet, Municipal Councilors, Mayor, Health Committee Members, and Village Development Committee Members)}

To take action now with Municipal Health Fund for improving essential medicines and primary health care financing with households, the Diaspora, public and private health actors, government and NGOs / Associations partnerships.

\section{References}

[1] Stinson W. Potential and limitations of community financing. World Health Forum, 1984; (5):123-125.

[2] OMS. Accès équitable aux médicaments essentiels : cadre d'action collective. Perspectives politiques de l'OMS sur les médicaments. $2004: 6$

[3] OMS. Réformes de la santé et financement des médicaments - Série " Économie de la santé et médicaments ». WHO/DAP. Genève, $1998:$ 20-60

[4] OMS. Rapport sur la santé dans le monde. Le financement des systèmes de santé : le chemin vers une couverture universelle. Genève, $2010:$ 20-60.

[5] World Health Organization. Coping with out-of- pocket health payments: application of engel curves and two-part models in six african countries. Discussion paper number 7 2007. Department health system financing. Geneva, 2007: 12-13.

[6] Direction Générale de l'Information et des Statistiques Sanitaires (DGISS)/ Ministère de la Santé. Tableau de bord santé 2009. Ouagadougou, $2010: 30-75$

[7] Institut National de la Statistique et de la Démographie (INSD)/ Ministère de l'économie et des finances. Recensement général de la population et de l'habitat de 2006. $2009: 45-80$.

[8] The World Bank. Development indicators. Washington, 2008 : 18-19

[9] Direction Générale de l'Information et des Statistiques Sanitaires (DGISS)/Ministère de la Santé. Tableau de bord santé 2009. Ouagadougou, $2010: 30-68$.

[10] Institut National de la Statistique et de la Démographie (INSD)/ Ministère de l'économie et des finances. Analyse des résultats de l'enquête annuelle sur les conditions de vie des ménages en 2003. Ouagadougou, $2003: 270$.

[11] Yunus M. Jolis A. Vers un monde sans pauvreté. J.C. Lattès, Paris, $1997: 345$

[12] Saouadogo H. Financement des médicaments essentiels par les ménages : Élaboration d'un système de prépaiement favorisant l'accès financier aux médicaments essentiels dans les pays en développement, District Sanitaire de Ouahigouya (Burkina Faso). Edition Universitaire Européenne. Sarrebruck, $2010: 140$.

[13] Ministère de la santé. Etats généraux de la santé. Ouagadougou, 2010

[14] PIMED. Pour améliorer la qualité des dons de médicaments : Compte rendu du colloque du 1er avril 2000. Paris; 2000

[15] Chirac P. Pour ou contre l'envoi dans le tiers-monde de médicaments inutilisés? Paris : La Revue Prescrire, 1987: 157.

[16] OMS. Comment élaborer et mettre en œuvre une politique pharmaceutique nationale $2^{\text {ème }}$ édition. OMS. Genève, $2002: 92$

[17] Institut National de la Statistique et de la Démographie (INSD)/ Ministère de l'économie et des finances. Recensement général de la population et de l'habitat de 1996. Ouagadougou, $2000: 315$ 
[18] DREES. Les bénéficiaires de la couverture médicale universelle au 31 décembre 2005 . Etudes et résultats $\mathrm{N}^{\circ} 512$. Ministère de la santé et des solidarités. Direction de la recherche, des études, de l'évaluation et des statistiques. Paris, 2006

[19] Ouedraogo J. Détermination et impact du risque moral sur la viabilité de l'AMBC de Nouna. Thèse de doctorat en pharmacie. Université de Ouagadougou (Burkina Faso), $2009: 118$

[20] USAID, Banque mondiale. Le Ghana et le Rwanda modèles de généralisation de l'assurance maladie en Afrique. ReMeD, 2009 : 2

[21] Vittecoq O. Les réformes des systèmes de protection sociale - Convergence et diversité. Revue Française des Affaires Sociales. Paris, $1999: 76$

[22] Jakab M, Krishnan C. Community involvement in health care financing : A Survey of the Literature on the Impact, Strengths, and Weaknesses. 2001

[23] Basaza R, Criel B, Van der Stuyft P, Criel B, and Van der Stuyft P. Low enrollment in Ugandan Community Health Insurance schemes: underlying causes and policy implications. BMC Health Services Research. 2007. (7):105.

[24] De Allegri M, Sanon M, Bridges J, and Sauerborn R. Understanding consumers' preferences and decision to enrol in community-based health insurance in rural West Africa. Health policy, 2006 ; 76(1): 58-71.
[25] Institut National de la Statistique et de la Démographie (INSD)/Ministère de l'économie et des finances. Bulletin trimestriel de conjoncture deuxième trimestre 2010. Ouagadougou, $2010: 75$

[26] Sankara T. Discours d'orientation politique. Octobre 1983, Ouagadougou, $1984: 14$

[27] Strandberg-Larsen M, Nielsen MB, Vallgårda S, Krasnik A, Vrangbæk K and Mossialos E. Denmark: Health system review. Health Systems in Transition, 2007; 9(6): 1-164.

[28] Vuorenkoski L, Mladovsky P and Mossialos E. Finland: Health system review. Health Systems in Transition. 2008; 10(4): $1-168$

[29] Teperi J, Porter EM, Vuorenkoski L and Baron FJ. The Finnish Health Care System: A Value-Based Perspective. Sitra Reports, Prima Ltd, 2009 : 20-112

[30] Norwegian Directorate of Health. Norway and Health an introduction. IS-1730 E. 2009 : 14-33

[31] Johnsen JR. Health Systems in Transition: Norway. Copenhagen, WHO Regional Office for Europe on behalf of the European Observatory on Health Systems and Policies, $2006: 31-51$

[32] Anell A, Glenngård AH, Merkur S. Sweden: Health system review. Health Systems in Transition, 2012, 14(5):1-159. 